\title{
KOMUNIKASI DALAM KELUARGA: UPAYA STRATEGIS MENCEGAH KEKERASAN PADA ANAK
}

\author{
Juniawati \\ Dosen FUAD IAIN Pontianak \\ Email: janiawati@yahoo.com
}

\begin{abstract}
Tumbubkembang anak baik fisik maupun fsikis adalah yang utama. Bangunan kepercayaan anak dalam menerima kasib sayang orangtua sepanjang pengasuban membutubkan bubungan interaksi yang kontinyu. Sepanjang perjalanan anak menuju dewasa tak jarang menimbulkan problem tersendiri bagi anak. Hubungan yang tidak harmonis, pemaksaan kehendak dan orangtua berposisi sebagai pemilik anak, sejatinya telah menjerumuskan anak sebagai korban dari perilaku orangtua. Sebingga tak jarang menimbulkan kekerberasan pada anak dalam berbagai bentuk yang terus saja menjadi trending topik di masyarakat. Kekerasan pada anak telab berakibat fatal pada perkembangannya dalam keluarga maupun lingkungan bal ini ditunjukkan dengan semakin meningkatnya kasus kekerasan maupun kejahatan pada anak. Memupuk komunikasi sejak dini menjadi salah satu pra syarat yang dibutubkan dalam membangun bubungan orangtua dan anak. Dalam Islam komunikasi ini dikenal mulai sejak dari dalam kandungan. Berbagai manfaat positif ditimbulkan dari bubungan komunikasi yang baik antara orangtua dan anak. Hal ini menjadi langkah terdekat bagi orangtua dan keluarga dalam mencegah meningkatnya kekerasan pada anak.
\end{abstract}

\section{PENDAHULUAN}

Anak adalah suatu proses tumbuh kembang suatu bangsa di masa depan yang memiliki sifat dan ciri khusus yang terletakpada sikap dan perilakunya dalam memahami dunia. Segala kejadian yang dialami di masa kecil adalah masa dimana anak perlu mengkompromikan segala sesuatu serta belajar untuk mengahadapi segala sesuatu baik kekalahan dan ketakutan yang tidak bisa dihadapi di masa kanaka-kanak akan terus dibawa sebagai pemicu kegagalan di masa dewasa. (Sumber Kementerian Pemberdayaan perempuan dan Anak, 2011).

Sebagai makhluk yang lemah, yang butuh banyak perhatian dan kasih sayang, anak mempunyai hak untuk memperoleh kehidupan yang layak, dibina dan didik dalam keluarganya. Bukan sebaliknya, anak dieksploitasi, anak mendapat kekerasan fisik maupun psikis sebagaimana yang terjadi di Indonesia beberapa tahun terakhir.

Sebagaimana kita ketahui, beberapa tahun terakhir, masyarakat Indonesia digemparkan oleh banyaknya kasus kekerasan terhadap anak. Parahnya, kekerasan yang terjadi pada anak dilakukan oleh orang-orang yang berada dekat dengan anak. Pelaku kekerasan itu berasal dari orangtua kandung, ayah atau ibu tiri atau orangtua angkat, paman, kakek, guru.

Di Indonesia terjadi peningkatan kasus kekerasan dari tahun 2010 hingga 410 kasus meningkat jadi 480 pada tahun 2011 dan 673 kasus pada tahun 2012. Data BARESKRIM POLRI menyebutkan bahwa selama 2010 s.d 2013 terdapat 467 kasus trafficking yang sebagian besar korbannya adalah anak perempuan. Jenis pekerjaan yang mengekspolitasi anak terbesar adalah eksploitasi seks komersial anak (ESKA) sebanyak 205 kasus, ekspolitasi ekonomi (pekerja anak) 
sebanyak 213 kasus (sumber kpai.go id). Belum lagi kasus kekerasan fisik yang dialami anak oleh anggota keluarga.

Kekerasan terhadap anak salah satu yang disebut dalam pengertian ekploitasi terhadap anak menurut Undang-undang RI Nomor 21 tahun 2007 tentang pemberantasan tindak pidana perdagangan orang (TPPO), adalah tindakan dengan atau tanpa persetujuan korban yang meliputi tetapi tidak terbatas pada pelacuran, kerja atau pelayanan paksa, perbudakan atau praktik serupa perbudakan, penindakan, pemerasan, pemanfaatan fisik, seksual, organ reproduksi atau secara melawan hukummemindahkan atau mentranspalansi organ dan atau jaringan tubuh atau memanfaatkan tenaga atau kemampuan seseoragn oleh pihak lain utnuk mendapat keuntungan baik materiil maupun immateriil. Kekerasan terhadap tiap tahunnya terus mengalami peningkatan. Kekersan terhadap anak seperti fenomena gunung es yang belum banyak diketahui, sementara jumlahnya kian hari kian meningkat. Sejak tahun 2011 terjadi 2178 kasus kekerasan, 20123512 kasus, tahun 2013 ada 4311 kasus dan 2014 terdapat 5066 kasus (sumber kpai.go id).

Kekerasan seksual anak dan ekspolitasi seksual komersial anak (ESKA) adalah bentuk penyalahgunaan kekuasaan dengan memanfaatkan seorang anak sebagai objek sesksual. Kasus terbesar persentasenya mencapai $91 \%$ adalah anak menjadi korban kekerasan dalam keluarga. Data terakhir memperlihatkan bahwa anak-anak menjadi korban kekerasan orang dewasa tercatat lebih dari 3 ribu kasus. Kasus yang kerap menjadi masalah serius yang menjurus ke masalah lain adalah penelantaran, kekerasan hingga anak berhadapan dengan hukum adalah kasus pengasuhan. Kasus pengasuhan menempati urutan kedua terbanyak yakni 3.160 kasus (sumber Pontianak Post, 24 Juli 2015).

Dengan demikian, menurut Komisi Perlindungan Anak Indonesia bahwa anak sangat rentan menjadi korban kekerasan di lingkungan rumah sendiri dan pelakunya adalah berasal dari kalangan yang dekat dengan anak. Dalam konteks kekerasan terhadap anak yang terjadi dalam lingkungan rumah atau keluarga, karena adanya anggapan bahwa orangtua memperlakukan anak bukan sebagai anak yang didengar pendapat, meiliki hak hidup dan bisa memilih kepentingan terbaiknya. Sebaliknya, orangtua memiliki kekuasaaan penuh teradap anak. Padahal ini merupakan pandangan yang salah. Sehingga komunikasi terjadi searah yang dalam hal ini orangtua dominan maka apabila perilaku anak tidak sesuai, anak rentan mendapat kekerasan.

Dalam hal ini, komunikasi dalam keluarga menjadi bagian yang tak terpisahkan dalam kehidupan anak sebagai unit terkecil dalam masyarakat dan yang terdekat dengan anak. Menurut Fitzpatrick, komunikasi dalam keluarga menenentukan sifat hubungan yang terjalin dan tidaklah bersifat acak (random) tetapi terpola dan menentukan bagaimana anggota keluarga berkomunikasi satu dengan yang lain (Morrisan, 2013). Inilah kemudian menjadi dasar bagaimana anak sebagai bagian dari keluarga mendapat perhatian yang semestinya dari anggota keluarga.

\section{KEKERASAN PADA ANAK}

Sebagaimana penulis sebutkan di atas,bahwa fenomena kekerasan terhadap anak seperti gunung es. Terjadi di sekitar kita tanpa mampu untuk diungkap. Sehingga terjadi berulang dan jumlahnya meningkat. Kekerasan pada anak menurut Undang-Undang Perlindungan Anak Nomor 35 tahun 2014 adalah setiap perbuatan terhadap anak yang berakibat timbulnya kesengsaraan atau penderitaan secara fisik, psikis, seksual dan atau penelantaran, termasuk 
ancaman untuk melakukan perbuatan, pemaksaan atau perampasan kemerdekaan secara melawan hukum.

Pertanyaanya, mengapa bisa terjadi? Dibawah ini setidaknya alasan yang menjadi kenyataan umum di masyarakat (Kementerian pemberdayaan Perempuan dan Perlindungan anak RI, 2011) bahwa:

1. Anak dipandang sebagai makhluk yang lemah, tidak berdaya dan tergantung sehingga orangtua atau orang dewasa di sekelilingnya punya kekuasaan yang harus dituruti anak. Tidak jarang diperlakukan secara otoriter oleh orangtua. Tidak jarang orangtua melupakan dampak perlakuan yang diterima anak dalam perkembangan kepribadian anak baik secara fisik terlebih mental.

2. Perkembangan anak-anak harus sesuai standar orangtua atau masyarakat pada umumnya, jadi orangtua atau orang dewasa lain berhak memberlakukan anak sesuai keinginannya, termasuk dengan kekerasan.

Sementara bentuk-bentuk kekerasan pada anak yang terjadi di masyarakat melihat defenisi kekerasan pada anak di atas adalah:

1. Penelantaran Terhadap anak

Penelantaran ini sebagai pemenuhan kebutuhan anak untuk berbagai keperluan baik makanan, pakaian, pendidikan atau medis maupun kasih sayang.

2. Kekerasan fisik.

Segala sesuatu agresi fisk yang diarahkan pada anak.

3. Pelecehan Seksual Anak.

Suatu bentuk penyiksaan anak untuk mendapat stimulasi seksual. Bentuknya berbagai macam, termasuk meminta atau menekan seorang anak untuk melakukan aktivitas seksual, paparan senonoh dari alat kelamin kepada anak, menampilkan pornografi pada anak, kontak seksual, kontak fisik dengan alat kelamin anak, melihat alat kelamin tanpa kontak fisik atau menggunakan anak untuk memproduksi pornografi anak.

4. Kekerasan Emosional/Psikologis

Kekerasan emosional bisa termasuk nama panggilan, ejekan, degradasi, perusakan harta benda, penyiksaan atau perusakan terhadap hewan peliharaan, kritik berlebihan, tuntutan yang tidak pantas atau berlebihan, pemutusan komunikasi dan pelabelan sehari-hari atau penghinaan. Akibatnya, anak bersikap pasif, kecenderungan menyalahkan diri sendiri, gangguan kasih sayang yang abnormal atau terganggu.

\section{HAK-HAK ANAK DALAM KELUARGA}

Secara hukum, Undang-Undang Dasar 1945 pasal 28 menyebutkan "setiap anak berhak atas kelangsungan hidup, tumbuh dan berkembang serta berhak atas perlindungan dari kekerasan dan diskriminasi. Selain itu, adanya kewajiban dan tanggung jawab orang tua terhadap anak sebagai bentuk perlindungan pada anak menurut pasal 26 Undang-Undang Perlindungan Anak nomor 35 tahun 2014:

1. Mengasuh, memelihara, mendidik dan melindungi anak

2. Menumbuhkembangkan anak sesuai dengan kemampuan, bakat dan minatnya

3. Mencegah terjadinya perkawinan pada usia anak 
4. Memberikan pendidikan karakter dan penanaman nilai budi pekerti pada anak.

Sebelum kita membincangkan hak-hak anak dalam keluarga, berikut beberapa kewajiban orangtua dalam pandangan Islam. Dalam Islam kasih sayang orang tua kepada anak telah diatur. Kewajiban ini diberikan semenjak anak dalam kandungan. Adanya hak anak menerima hak keperawatan dan pemeliharaan (al-hadanab) oleh orangtua dipahami sebagai pemeliharaan secara menyeluruh, baik dari segi kesehatan fisik, mental, perkembangan pengetahuannya (Lajnah Pentashih Mushaf Al-qur'an, 2014).

Kewajiban yang juga merujuk pada dukungan pertumbuhan dan mendidik secara jasmani serta memberikan nilai-nilai kebaikan dengan bekal ajaran Islam juga budaya hidup dalam masyarakat menjadi hal penting dalam pemeliharaan anak. Pentingnya, memberikan pendidikan kepada anak sebagai bentuk keprihatinan terhadap meningkatnya kasus penelantaran, kekerasan hingga kasus anak berhadapan dengan hukum. Menurut Menteri Agama RI Lukman Hakim Saifuddin, menempatkan pendidikan agama pada anak sebagai acuan sekaligus kunci untuk menjalani hidup di masyarakat (Sumber: Pontianak Post 24 Juli 2015). Sebab anak merupakan anugerah dari Allah dan kelanjutan dari orangtua sebagai generasi penerus yang memiliki pondasi agama dan kepribadian yang kuat dan berakhlak baik. Firman Allah dalam surat An-Nisa 4:9 disebutkan:

"Dan hendaklah takut (kepada Allah) orang-orang yang sekiranya mereka meninggalkan keturunan yang lemah di belakang mereka yang mereka khawatir terhadap (kesejahteraan)-nya. Oleh sebab itu, hendaklah mereka bertakwa kepada Allah dan hendaklah mereka bebicara dengan tutur kata yang benar"

Dalam ayat tersebut di atas, mengisyaratkan konteks hak perawatan dan pemeliharaan juga jatuh pada Ayah sebagai pemberi nafkah. Sebagai imbangannya, kewajiban anak adalah berbuat baik kepada orangtua sekalipun berbeda agama dan keyakinan. Hal ini tidak lantas menggugurkan perbuatan baik anak kepada orangtua. Fiman Allah dalam Al-qur'an Surat Al-Isra 17:23 dan surat Lukman 31: 15 (Lajnah Pentashih Mushaf Al-qur'an, 2014) yang artinya:

"Dan Tuhanmu telah memerintahkan agar kamu jangan menyembah selain Dia dan hendaklah berbuat baik kepada ibu bapak. Jika salah seorang diantara keduanya atau kedua-duanya sampai berusia lanjut dalam pemeliharaanmu, maka sekali-kali janganlah engkau mengatakan kepada keduanya perkataan "ah" dan janganlah engkau membentak keduanya, dan ucapkanlah kepada keduanya perkataan yang baik" (Surat Al-Isra 17:23)

"Dan Jika keduanya memaksamu untuk mempersekutukan Aku dengan sesuatu yang engkau tidak mempunyai ilmu tenang itu, maka janganlah engkau menaati keduanya, dan pergaulilah keduanya di dunia dengan baik" (Lukman 31: 15)

Nabi Muhammad SAW, sebagai pemberi contoh orang yang sangat mengasihi dan menyanyangi anak. Nabi Muhammad SAW juga menerima dan menghargai nasehat anak. Menerima kebenaran meski datangnya dari anak, bahkan anak berhak menjadi imam atau pemimpin bila mampu dari segi ilmu pengethauan terhadap Al-qur'an di banding orang dewasa (Muhammad Ibnu Abdul Hafidh Suwaid, 2004). Rasulullah SAW bersabda yang artinya: 
"Sembahlah Allah dan jangan kau sekutukan dengan yang lain! Berjalanlah kamu bersama Al-qur'an kemana pun berada! Terimalah kebenaran dari siapapun, baik dari anak kecil ataupun orang dewasa, meskipun dia adalah orang jauh yang kamu benci! Dan tolaklah kebatilan dari siapapun, baik anak kecil atau orang dewasa, meskipun itu adalah orang dekat yang kamu cintai!" (HR. Ibnu Asaakir dan AdDailami)

Petunjuk Islam dalam mengatur hak anak dan kewajiban orang tua mengandung arti dimana secara hubungan antar anggota keluarga menjadi sarana interaksi, sekaligus sebagai upaya menciptakan komunikasi yang intensif sehingga keadaan keluarga senantiasa kondusif dan harmonis. Orang tua dicontohkan nabi sebagai pemberi pengaruh terbesar dalam memenangkan gejolak dan geloa jiwa anak. Oleh karena itu, perlu upaya membangun kepribadian seorang anak dan memberikan hak-haknya (Muhammad Ibnu Abdul Hafidh Suwaid, 2004) seperti:

1. Memberi ciuman, perhatian dan kasih sayang

Bukhari dan Muslim meriwayatkan bahwa Aisyah ra. berkata:

"Beberapa orang Arab badui datang kepada Rasulullah SAW. Mereka bertanya,'Apakah kailan mencium anak-anak kalian?’YYa, jawab Rasulullah SAW. Tapi

kami, demi Allah, sekali-kali tidak pernah mencium mreka (anak-anak kami). Maka Rasulullah SAW bersabda, Saya tidak memiliki kekuatan sekiranya Allah SWT, mencabut perasaan kasih sayang dari hati kalian"

2. Bermain dan bercanda dengan anak

Sebagai sebuah kewajiban, orang tua mesti memberikan kewajiban pendidikan dengan mencontoh sunnah rasul dengan bercanda dan bermain dengan anak. Karena lewat canda dan bermain dengan anak sebagai bentuk interaksi orangtua dengan anak dan sekaligus memenuhi jiwa anak dengan perasaan kasih sayang yang tulus yang tidak dibuat-buat, sehingga jauh dari sikap kasar.

3. Memberikan hadiah, penghargaan dan pujian kepada anak

Memberikan hadiah, penghargaan dan pujian kepada anak membawa pengaruh positif dan bermanfaat. Prinsip ini sebagai upaya membangun, mengarahkan dan mendidik jiwa serta perasaan anak. Sebagaimana disebutkan dalam sebuah riwayat Nabi Muhammad SAW berdoa:

"Ya Allah berkahilah di negeri kami dan dalam buah-buahan kami, dalam mud dan sha', dengan keberkahan demi keberkahan.” Kemudian Rasulullah SAW memberikannya kepada anak terkecil yang hadir. (HR. Muslim dari Abu Hurairah ra)

4. Mengusap kepala anak

Tindakan mengusap kepala anak merupakan wujud perhatian dan pemberian kebahagiaan kepada anak.

5. Menyambut anak dengan kebahagiaan

Pertemuan dengan anak akan mampu memberi pengaruh persuasif pada anak. Anak akan mengikuti percakapan dan pembicaraan. Sambutan yang baik dari orangtua kepada anak akan membuka jiwa anak untuk bicara dan anak menyampaikan masalahnya.

6. Memperhatikan dan menanyakan keadaan anak

Sebagai orangtua, meski mempunyai sikap tanggap pada anak. Perhatian ini merupakan upaya menjaga kestabilan jiwa anak. Kekurangtanggapan orangtua pada anak akan 
memunculkan perasaan cemas, kekhawatiran dan ketakutan anak. Kegundahan anak akan semakin menjadi, ketika orangtua tidak tanggap dengan keadaan anak.

Mengenai hak-hak anak, merujuk pada Konvensi hak-hak anak Perserikatan BangsaBangsa (United Nations Convention On The Rights Of The Child) yang mengatur hak-hak sipil, politik, ekonomi, sosial dan kultural anak-anak, maka Indonesia memiliki kewajiban melaksanakan hak-hak anak yang terbagi dalam 5 kluster yang diuraikan bahwa anak mempunyai hak berikut ini:

1. Bermain

2. Berkreasi

3. Berpartisipasi

4. Berhubungan dengan orangtua bila terpisahkan

5. Bebas beribadah menurut agamanya

6. Bebas berkumpul

7. Bebas berserikat

8. Hidup dengan orangtua

9. Kelangsungan hidup, tumbuh dan berkembang

Hak untuk Pendapatan:

1. Nama

2. Identitas

3. Kewarganegaraan

4. Pendidikan

5. Informasi

6. Standar kesehatan paling tinggi

7. Standar hidup yang layak

Hak mendapat Perlindungan:

1. Pribadi

2. Dari tindakan/penangkapan sewenang-wenang

3. Dari perampasan kebebasan

4. Dari perlakuan kejam, hukuman dan perlakuan tidak manusiawi

5. Dari siksaan fisik dan non fisik

6. Dari penculikan, penjualan dan perdagangan atau trafficking

7. Dari eksploitasi seksual dan kegunaan seksual

8. Dari eksploitasi atau penyalahgunaan obat-obatan

9. Dari eksploitasi sebagai pekerja anak

10. Dari eksploitasi sebagai kelompok minoritas atau kelompok adat terpencil

11. Dari pemandangan atau keadaan yang menuut sifatnya belum layak untuk dilihat anak

12. Khusus dalam situasi genting/darurat

13. Khusus sebagai pengungsi atau orang yang tergusur

14. Khusus jika mengalami konflik hukum

15. Khusus dalam konflik bersenjata atau konflik sosial 


\section{MEMBANGUN KOMUNIKASI DALAM KELUARGA}

Dalam sebuah tulisan disebutkan di media massa Kompas, bahwa jika orangtua mengabaikan akan pentingnya menjalin komunikasi dengan anak, maka orangtua akan kehilangan kesempatan untuk memberikan yang terbaik bagi pertumbuhan dan perkembangan kepribadian atau karakter anak. (sumber: Kompasiana.com. 30 April 2014).

Kegagalan komunikasi (miscommunication) dengan anak bisa berpengaruh pada pertumbuhan anak, baik secara intelektualistas dan kualitas hidup anak. Dalam beberapa kajian menunjukkan bahwa komunikasi interpersonal antara orangtua dan anak dapat terjalin dengan baik melalui komunikasi. Dalam tugas akhir Mila Fajawati 2011 menyebutkan komunikasi yang demokratis antara orangtua dengan anak bisa mendatangkan perkembangan perilaku anak yang baik. Komunikasi demokratis ditandai dengan adanya sikap terbuka antara orangtua dengan anak, dengan membuat kesepakatan-kesepakatan bersama dan orangtua menghargai kemampuan anak.

Donna Isra Silaban dkk (2015) dalam penelitiannya mengisyaratkan pentingnya komunikasi orangtua pada remaja. Mengembangkan pemahaman mengenai diri sebagai proses berkomunikasi bersama orang lain, biasanya dimulai dari keluarga terutama dalam menemukan dan menampilkan kapasitas identitas diri di sepanjang usia kehidupan untuk mendapatkan konsep diri secara jelas adalah berawal dari orangtua.

Proses komunikasi sangat berpotensi dalam mempengaruhi dan membujuk. Komunikasi yang dilakukan orang tua pada anak secara intens berupa percakapan atau dialog, mampu menghasilkan sikap saling menghargai. Anak tidak merasa diabaikan. Pembicaraan yang dilakukan orangtua dengan positif membantu anak dalam mengembangkan dirinya secara positif mulai dari lingkungan keluarga. Sebaliknya, orangtua yang cenderung sesuka hati berbicara dan acuh tak acuh pada anak atau remaja, menjadikan anak merasa tersudut dan ragu ketika bertindak (e-jurnal 'Acta Diurna tahun 2015).

Komunikasi dalam keluarga sekilas kedengarannya sederhana dan mudah dilakukan. Padahal, dalam realitasnya di masyarakat tidak sedikit dari keluarga yang mengalami kebekuaan dalam berkomunikasi atau berkomunikasi tanpa melihat kondisi maupun kebutuhan anggota keluarga, tidak terkecuali pada anak.

Adapun komunikasi (communication) mengacu pada sama makna. Komunikasi dalam bahasa arab dikenal dengan istilah tawashul dan ittishal. Tawashul berarti proses yang dilakukan oleh dua belah pihak untuk saling bertukar informasi sehingga pesan yang disampaikan dipahami atau sampai kepada dua belah pihak yang berkomunikasi. Adapun ittishal lebih fokus pada aspek ketersambungan pesan, tidak harus terjadi komunikasi dua arah. Maksudnya, jika salah satu pihak menyampaikan pesan dan pesan itu sampai dan besambung dengan pihak yang dimaksud, maka pada saat itu sudah terjadi komunikasi (Harjani, 2014)

Lebih jauh, dalam buku Komunikasi Islam (lihat Harjani, 2014) menjelaskan bahwa komunikasi sebagai proses penyampaian suatu pernyataan oleh seseorang kepada orang lain. Menurut Halah dalam Fann al-tawwashul fi al-Islam menyebut bahwa komunikasi adalah hubungan terbaik. Definisi ini lebih menekankan kepada kualitas komunikasi dalam tiga bentuk yaitu komunikasi dengan Pencipta, komunikasi dengan diri sendiri, dan komunikasi dengan sesama manusia. 
Selanjutnya, komunikasi berkaitan dengan penyampaian sesuatu dalam rangka mendapatkan kesamaan makna. Harold Laswell dalam karyanya The Structure And Function Of Communication In Society, dengan model komunikasi, memberikan pengertian "who says to whom in what channel with what effect ". Komunikasi sebagai suatu proses penyampaian pesan dari komunikator yang ditujukan kepada komunikan melalui media atau saluran yang menimbulkan efek tertentu. Dari istilah tersebut unsur komunikasi yaitu komunikator (communicator, source, sender), pesan (message) dan komunikan (communicant, receiver, recepient), media (channel) dan terakhir efek (effect, impact, influence).

Komunikator juga mempunyai beberapa sifat umum:

1. Sifat neurotisme atau kecenderungan untuk merasakan emosional negatif dan perasaan tidak bahagia (menderita)

2. Sifat ekstraversi atau kecenderungan untuk senang begaul, menyukai keompok lain, percaya diri dan berfikir optimis

3. Sifat terbuka (openness) atau kecendeungan untuk menyukai dan bersimpati terhadap orang lain, suka membantu atau menolong orang lain serta cenderung menghindari pertentangan (antagonisme)

4. Sifat hati-hati atau kecenderungan untuk bersikap disiplin (self disciplined), tidak mudah menurut kata hati, teratur (well organized) serta menyelesaikan tugas dengan tuntas.

Adapun pesan atau message ditunjukkan dalam bentuk verbal (bahasa) atau non verbal (non bahasa) dan secara lisan, tertulis atau gambar. Bentuk pesan seperti diilustrasikan R. Wayne Pace dan Don F. Foulus (2013) sebagai berikut:

\begin{tabular}{lll}
\hline & Verbal & Nonverbal \\
\hline Lisan & Wawancara & Berbicara pelan \\
Tertulis & Laporan & Diagram atau tata letak \\
Gambar & Uraian suatu adegan & Sketsa suatu adegan \\
\hline
\end{tabular}

Melihat bentuk pesan di atas, berdasarkan perspektif perilaku, Skinner menjelaskan lebih sederhana bahwa komunikasi sebagai perilaku verbal atau simbolis di mana sender berusaha mendapatkan suatu efek yang dikehendakinya pada receiver. Demikian juga Dance yang melihat simbol atau lambang yang ditampilkan dalam proses komunikasi sebagai karena adanya satu respons melalui lambang-lambang verbal dimana simbol verbal tersebut bertindak sebagai stimulus untuk memperoleh respons (Sandjaja 2002 yang dikutip Burhan Bungin 2008).

Penerapan komunikasi dalam kehidupan sehari-hari yang dilakukan oleh source dalam hal ini bisa individu atau kelompok. Untuk mempermudah melihat proses komunikasi berlangsung dari definisi istilah komunikasi yang penulis uraikan di atas dapat dipahami dalam dua bentuk umum dalam tindakan komunikasi yang terjadi:

1. Penciptaan pesan atau lebih tepatnya penciptaan pertunjukan (display) dan

2. Penafsiran pesan atau penafsiran pertunjukan

Langkah pertama yang dilakukan source atau individu/kelompok adalah ideation dengan individu lain. Ideation sebagai landasan pesan satu gagasan atau pemilihan informasi untuk dikomunikasikan. Langkah kedua, dalam penciptaan pesan adalah encoding, dimana source atau sumber menerjemahkan info atau gagasan dalam wujud kata, tanda atau lambang dan diharap 
dapat menimbulkan efek pada orang lain. Adapun pesan atau message adalah alat-alat dimana sumber mengekspresikan gagasan dalam bentuk bahasa lisan, tertulis atau perilaku non verbal. Langkah ketiga dalam proses komunikasi yakni menyampaikan pesan yang telah disandi (encode). Sumber menyampaikan pesan kepada penerima dengan cara berbicara, menulis atau melalui tindakan tertentu. Pada langkah ketiga ini dikenal channel atau saluran. Bentuknya bisa berupa menggunakan alat atau media seperti radio, tv, telepon dll (diringkaskan dari Model Komunikasi antar manusia oleh Jerry W. Koehler, Karl W.E. Anatol, Ronald L. Appibaum, Burhan Bungin, 2008).

Dalam komunikasi, keluasan dan kedalaman hubungan berbeda-beda. Altman dan Dalmas Taylor (1973; Taylor dan Altman, 1987) mengetengahkan diantara hubungan yang lebih dekat lagi adalah hubungan seseorang dengan orang tua atau saudara kandung. Dalam hubungan komunikasi ini, bisa terjadi banyak topik yang diperbincangkan.

Hal ini digambarkan dalam penetrasi sosial (Devito, 1997) daya tarik antar pribadi memperlihatkan hubungan dapat lebih dekat dan berkembang dipengaruhi beberapa faktor daya tarik:

1. Daya tarik (fisik dan kepribadian)

2. Kedekatan (proksimitas)

Jarak fisik dan kekerapan seseorang ikut menentukan hubungan

3. Pengukuhan

Menghargai berupa pujian atau bersifat material (berupa hadiah atau promosi)

4. Kesamaan

Kesamaan sikap, keserdasan fisik, kecerdasan dan selera membantu daya tarik dalam komunikasi

5. Komplementaritas

Sifat melengkapi dimaknai sebagai suatu yang berlawanan bisa menjadi daya tarik sebagai

bentuk saling melengkapi

Dalam beberapa penjelasan mengenai pengaruh komunikasi dalam meningkatkan kualitas hubungan, meletakkan proses dialog dalam komunikasi yang mempunyai keutamaan. Mikhael Bakhtin (Morissan, 2013) menyatakan bahwa dialog pada dasarnya adalah penjelasan mengenai hubungan (relationship). Dialog atau ucapan merupakan suatu unit pertukaran lisan atau tulisan, diantara dua orang. Suatu ucapan mempunyai tema yaitu isi percakapan, sikap komunikator terhadap subjek yang menjadi lawan bicarnya dan derajat tanggapan dari lawan bicara. Melalui ucapan atau pembicaraan dapat diperoleh: Pertama, dapat menicptakan momen atau peluang atau sering kali titik balik yang akan diingat sebagai hal yang penting dalam hidup. Kedua pada saat yang sama, terlihat adanya perbedaan diri orang lain selama menjalin hubungan, Dialog juga memberikan peluang untuk mencapai kesatuan dalam perbedaayang dikatakan orang lain.

Ketika kita melakukan dialog menurut Carl Rogers, maka kita menghubungkan diri kita dengan orang lain melalui empat cara:

(1) Kita hadir dan terhubung (nyambung) dengan apa yang dikatakan orang lain;

(2) Kita menjadi kongruen (saling mendukung dan memperkuat)

(3) Kita Menunjukkan perhatian positif

(4) Memiliki empati yaitu memahami dari mana seseorang berasal (latar belakangnya) 
Sementara istilah keluarga dalam kamus bahasa Indonesia (Tanti Yuniar Sip) berarti orang-orang yang menjadi penguhi rumah, seisi rumah; bapak beserta rumah dan anaknya; satuan kekerabatan yang mendasar dalam masyarakat.

Keluarga menjadi lembaga pertama bagi kehidupan anak, menjadi tempat pertama dalam bersosialisasi; menjadi tempat menggantungkan harapan yang paling besar. Hubungan keluarga dalam pandangan komunikasi di bagi pada tiga:

1. Apa yang diketahui seseorang mengenai hubungan secara umum

2. Apa yang diketahuinya mengenai hubungan keluarga sebagai suatu tipe

3. Apa yang diketahui mengenai hubungan dengan anggota keluarga lainnya.

Komunikasi orangtua pada anak, menurut Muhammad Rizal, (sumber: Kompas.com) ada beberapa pendekatan dalam membangun komunikasi dengan anak. Hal ini sebagai upaya komunikasi untuk memperoleh respon atau tanggapan anak. Pendekatan berkomunikasi dengan anak ini berdasarkan karakter anak yang berbeda-beda.

1. Hard Bargainer

Posisi orangtua dengan gaya ini sangat otoriter. Kemauan dan semua arahan hanya benar dari orangtua. Anak tidak mendapat porsi yang semestinya dihargai atau didengar, sebaliknya unsur paksaan dan memberi menghukum lebih diperkuat

2. Collaborator

Keterlibatan anak-anak dalam mengambil keputusan sangat diutamakan. Komunikasi diarahkan lebih besar dengan cara bekerjasa sama dengan anak. Hal ini menunjukkan adanya sikap keterbukaan orangtua dengan anak demikian juga sebaliknya, sehingga yang terjadi adalah saling menghargai pendapat satu dengan yang lain.

3. Conflict Avoide

Orangtua lebih bersikap cuek atau mendiamkan perilaku anak berkembang bebas. Sehingga komunikasi jarang terjadi. Ini didasarkan oleh keinginan orangtua yang tidak menginginkan konflik dengan anak.

4. Accomodator

Seperti namanya, komunikasi orang tua dengan anak, cenderung mengikuti keinginan anak. Komunikasi yang terjalin lebih mengedepankan kebebasan anak dalam berekspresi, bereksperimen maupun bereksplorasi.

\section{REFERENSI}

Burhan Bungin. 2008. Sosiologi Komunikasi. Jakarta: Kencana Prenada Media Group

Devito. A. Joseph. 1997. Komunikasi Antar Manusia. Jakarta: Profesional Books

Donna Isra Silaban dkk. Komunikasi Antar Pribadi Orang Tua Dalam Pembentukan Konsep Diri Remaja Pada Keluarga di Lingkungan III Kelurahan Bahu. e-jurnal "Acta Diurna” Vol. IV. No.3 tahun 2015

Harjani Hefni. 2014. Komunikasi Islam. Pontianak: IAIN Pontianak Press

Kompas. Pentingnya Menjalin Komunikasi Orang Tua dan Guru Dalam Membangun Karakter Anak. www. kompasiana.com. 30 April 2014. Diakses Juli 2015.

Lajnah Pentashih Al-qur'an. Tafsir Tematik. Kementerian Agama Republik Indonesia Morrisan. 2013. Teori Komunikasi. Individu Hingga Massa. Jakarta: Kencana Prenada Media Group

Muhammad Ibnu Abdul Hafidh Suwaid. 2004. Cara Nabi Mendidik Anak. Jakarta: Al-I’Tishom Cahaya Umat 
Muhammad Rizal, Psi. Gaya Komunikasi Orang Tua dan Anak. www. kompas.com. 6 November 2010. Diakses Maret 2015.

Pace, R. Wayne dan Don F. Foulus. 2013. Komunikasi Organisasi. Bandung: Remaja Rosdakarya Pontianak Post. 24 Juli 2015. Ribuan Anak masih Merana.

Tanti Yuniar Sip. Tt. Kamus Bahasa Indonesia. Agung Media Mulia

\section{Sumber Skripsi}

www.eprints.upjnjatim.ac.id. Mila Fajawati. 2011. Pola Komunikasi Orang Tua Dengan Anak Remaja Dalam Berinternet Sehat di Surabaya. Diakses Januari 2015 